\title{
TECHNICAL NOTE \\ ASSESSMENT OF THE WATER QUALITY OF BOREHOLES IN THE ABURI MUNICIPALITY OF EASTERN REGION OF GHANA
}

\author{
J. Apau $^{1}$, H. K. Agbovi ${ }^{1}$ and D. D. Wemegah ${ }^{2}$ \\ ${ }^{1}$ Department of Physics, KNUST, Kumasi \\ ${ }^{2}$ Department of Physics, KNUST, Kumasi \\ Corresponding author: apaujoseph@yahoo.com
}

\begin{abstract}
Ground water samples from 32 boreholes in 17 communities within Aburi and its environs were sampled and analysed within the period of October 2008 to January 2009 for various physicochemical water quality parameters. The study showed that most of the physico-chemical parameters were within the World Health Organization limits recommended for drinking water. All the water samples were found to be colourless, with turbidity of $0.00 \mathrm{NTU}$. Temperature ranged from 24.0 to $28.0^{\circ} \mathrm{C}$, with an average of $26.21 \pm 1.57^{\circ} \mathrm{C}$. The $\mathrm{pH}$ values ranged from 6.38 to 7.28 with an average of $6.38 \pm 0.21$. The TDS of the water samples ranged from 13 to $522 \mathrm{mg} / \mathrm{L}$ with an average of $85.19 \pm 53.85$. Alkalinity levels were low ranging from 10 to $260.34 \mathrm{mg} / \mathrm{L}$ with a mean of $51.16 \pm 37.51 \mathrm{mg} / \mathrm{L}$ whereas conductivity recorded values ranging from 18.98 to $240 \mu \mathrm{S} /$ $\mathrm{cm}$ and an average of $82.15 \pm 43.10 \mu \mathrm{S} / \mathrm{cm}$. The total hardness had a range of 25 to $301 \mathrm{mg} / \mathrm{L}$ with an average of $95.46 \pm 59.01 \mathrm{mg} / \mathrm{L}$. Most of the boreholes showed low level of mineralization. Low levels of nitrates ranging from 0.11 to $1.00 \mathrm{mg} / \mathrm{L}$ with an average of $0.665 \pm 0.24 \mathrm{mg} / \mathrm{L}$ were recorded. Low levels of sulphate ranging from 35.35 to $200.48 \mathrm{mg} / \mathrm{L}$ with a mean of $93.75 \pm$ $49.98 \mathrm{mg} / \mathrm{L}$ were obtained. Phosphate ion concentration ranging from 0.5 to $5.8 \mathrm{mg} / \mathrm{L}$ with an average of $2.64 \pm 1.423 \mathrm{mg} / \mathrm{L}$ and chloride ion concentration ranging from 21.27 to $131.17 \mathrm{mg} / \mathrm{L}$ with a mean of $66.02 \pm 30.28 \mathrm{mg} / \mathrm{L}$ were also obtained. All the water was found to be "salinityfree." The study showed that the borehole water in the municipality is potable.
\end{abstract}

Keywords: groundwater, borehole, physico-chemical, environs

\section{INTRODUCTION}

With the ever increasing Worlds population, provision of good quality drinking water is a challenge for governments especially in developing countries. Nearly one billion people lack access to safe drinking water worldwide. People therefore have resorted to the use of hand dug wells, boreholes and river water for their domestic, agriculture and industrial uses. However, no proper treatment is carried out on water from these sources before use. It is estimated that about half of the world's hospital beds are occupied by patients suffering from diseases associated with lack of access to safe 
drinking water, inadequate sanitation and poor hygiene (UNICEF/WHO, 2008).

Water is necessary for the healthy development of man, animals and plants. Developing countries are witnessing deterioration in quality as well as depletion of ground water which constitute another source of potable water. The preference for ground water to surface water may be due to the need for purification of the latter prior to distribution (Adeyeye, 2004). Generally speaking groundwater is characterized by low temperature, low redox potential, high carbon dioxide and mineral content, less amount of suspended solids and free from microbial contaminants (Pant, 2010). Groundwater pollution in urban areas is mostly due to infiltration of urban storm water, leakage of waste waters and septic reservoirs and improper industrial activities (Robertson et al., 1991; Jeong, 2001; Rivett et al., 2002; Dechesne et al., 2004). The waste waters and septic system effluent contain high concentration of dissolved organic carbon, ammonia, pathogens and organic micro pollutants as well as heavy metals and trace elements. Drinking water plays an important role in the oral intake of trace elements in human beings. Physico-chemical characteristics of drinking water are therefore very important in determining its suitability for usage. Significant variations in physico-chemical parameters affect the quality of a water resource. Hence, it is necessary to obtain information on the variations of seasonal physico-chemical characteristics of water resources in order to decide on the type of water treatment process to be adopted. Even though some of the trace elements found in water are essential to man, at elevated levels, they cause morphological abnormalities, reduce growth, increase mortality and mutagenic effects (Asaolu, 2002).

Scientists estimate that ground water makes up $95 \%$ of all freshwater available for drinking. Ground water is a significant source of water for many municipal water systems in Ghana. Rural residents, drawing their water from wells, also rely on this source of water. Groundwater is also often withdrawn for agricultural, municipal and industrial use by constructing and operating extraction wells. The study of the distribution and movement of groundwater is hydrogeology, also called groundwater hydrology (Ludwig et al., 1993).

Aburi is a town located in the Eastern Region of Ghana on a mountain usually called the Akuapim Mountain. Because of the town's mountainous location, the tap water hardly flows and dwellers have resorted to boreholes and wells for survival.

Despite the proliferation of boreholes, not much information exists on the quality of ground water in Ghana, because it is assumed that ground water is naturally pure and free from infections.

The World Health Organization (WHO), in 1996 established specific permissible or tolerable levels of chemical pollutants allowable in water bodies. Water quality assessment is carried out on a regular basis to ensure that potable water such as borehole water is safe for drinking. It is in consequence of this that the study was undertaken.

\section{METHODOLOGY}

\section{Sampling}

Polyproylene bottles treated with nitric acid and rinsed with distilled water were used for the water sampling. Fig. 1 is the map of the study area. Samples were taken from the following communities; Domeabra, Jamaica, Asuafum, Presbyterian Women Training College (PWTC), Obodan, Pokrom, Prisons, Fotobi, Kwesi Doi (KD), Abetema, Asheresu, Dago, Afutu and Yaw Nyarko as well as some second cycle institutions such as the Presbyterian Secondary Technical School (Sectech), Aburi Girls' Schoool (AG), and Adonteng Senior High School in the Aburi municipality. Samples were taken between October 2008 and January 2009. One sample was taken from each site monthly. Samples were stored in freezers at a temperature of about $4{ }^{\circ} \mathrm{C}$ after the physical 
Physico-chemical water quality parameters ... 9

91

parameters had been determined on site. The numbers written on some communities give the number of boreholes sampled in that particular area. Some values were outliers and failed the Q-test.

\section{Experimental methodology}

Standard methods prescribed in American Public Health Association (APHA, 1998) and the Environmental Protection Agency of America was used to analyse the water samples. The $\mathrm{pH}$, temperature, conductivity and total dissolved solids (TDS) were determined on site. A Portable Hach $\mathrm{pH}$ meter calibrated with buffers 4 , 10 , and 12 was used for the $\mathrm{pH}$ readings. A Calibrated Portable Hach Sension 5 conductivity meter was used to measure the temperature, conductivity and total dissolved solids in the water. The turbidity was measured with a Hach 2100 P turbidimeter. Salinity was measured with a WTW conductivity 330i meter. Alkalin- ity and total hardness were determined by titrimetric method whereas chloride was determined by the Mohr Argentometric method. Sulphate, phosphate and nitrate were determined by colorimetric method using a colorimeter (HACH DR/890).

\section{RESULTS AND DISCUSSION}

The quality of a water resource depends on the management of anthropogenic discharges as well as the natural physico-chemical characteristics of the catchment areas. Generally, over the years, countries all over the world have adopted US- EPA or WHO standards for borehole water, tap water as well as bottled water as the ultimate specification for water used for domestic purposes. The physical and chemical water quality parameters are presented in $\mathrm{Ta}$ bles 1 and 2. Table 3 is the averages of the water parameters compared with the WHO/EPA Guidelines.

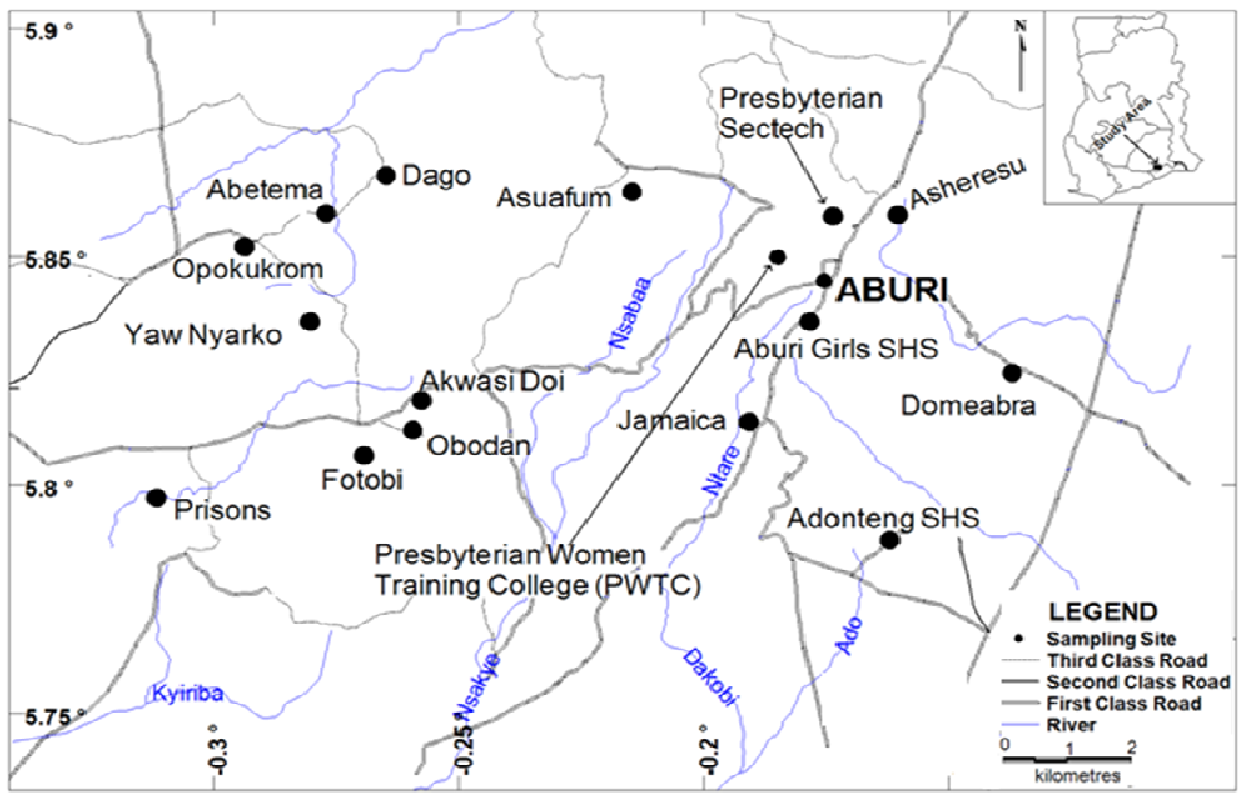

Fig. 1: Map of Aburi Municipality showing the study areas 
Table 1: Physical water quality parameters

\begin{tabular}{|c|c|c|c|c|c|c|c|c|c|}
\hline $\begin{array}{l}\text { Town/ } \\
\text { source }\end{array}$ & pH & $\begin{array}{l}\text { Temp/ } \\
{ }^{\circ} \mathrm{C}\end{array}$ & $\begin{array}{l}\text { Alk./ } \\
\text { mg/L }\end{array}$ & $\begin{array}{l}\text { Cond./ } \\
\mu S / c m\end{array}$ & $\begin{array}{l}\text { T.H./ } \\
\mathrm{mg} / \mathrm{L}\end{array}$ & $\begin{array}{l}\text { Turb./ } \\
\text { NTU }\end{array}$ & Salinity & $\begin{array}{l}\text { TDS/ } \\
\mathrm{mg} / \mathrm{L}\end{array}$ & Colour \\
\hline Domeabra & 6.86 & 24.6 & 25.55 & 71.2 & 109 & 0.00 & 0.00 & 175 & $\mathrm{CL}$ \\
\hline Jamiaca 1 & 6.73 & 25.4 & 10.00 & 39.4 & 72 & 0.00 & 0.00 & 113 & CL \\
\hline Jamiaca 2 & 6.71 & 24.4 & 20.00 & 53.6 & 45 & 0.00 & 0.00 & 162 & CL \\
\hline Asuafum 1 & 6.84 & 25.5 & 20.00 & 108.8 & 125 & 0.00 & 0.00 & 409 & CL \\
\hline Asuafum 2 & 6.76 & 24.4 & 15.00 & 46.4 & 69 & 0.00 & 0.00 & 148 & CL \\
\hline PWTC & 6.70 & 25.2 & 17.50 & 63.2 & 100 & 0.00 & 0.00 & 205 & CL \\
\hline Sectech 1 & 6.90 & 24.3 & 45.90 & 37.1 & 40 & 0.00 & 0.00 & 26 & CL \\
\hline Sectech 2 & 6.54 & 27.9 & 48.50 & 18.98 & 25 & 0.00 & 0.23 & 13 & CL \\
\hline Sectech 3 & 6.56 & 27.3 & 80.50 & 30.4 & 32 & 0.00 & 0.00 & 21 & CL \\
\hline Obodan 1 & 6.82 & 24.4 & 15.00 & 157.0 & 46 & 0.00 & 0.00 & 157 & CL \\
\hline Obodan 2 & 6.75 & 27.7 & 80.85 & 90.8 & 67 & 0.00 & 0.00 & 63 & CL \\
\hline Pokrom1 & 6.82 & 24.4 & 40.00 & 37.1 & 238 & 0.00 & 0.00 & 421 & CL \\
\hline Pokrom 2 & 6.88 & 28.0 & 80.30 & 144.9 & 230 & 0.00 & 0.00 & 99 & CL \\
\hline Fotobi 1 & 6.78 & 24.6 & 27.50 & 134.8 & 200 & 0.00 & 0.00 & 109 & CL \\
\hline Fotobi 2 & 6.80 & 27.7 & 61.00 & 138.3 & 160 & 0.00 & 0.00 & 94 & CL \\
\hline $\mathrm{KD}$ & 6.87 & 26.5 & 17.50 & 29.7 & 51 & 0.00 & 0.00 & 193 & CL \\
\hline AG 1 & 6.85 & 24.0 & 20.00 & 105.0 & 182 & 0.00 & 0.01 & 526 & CL \\
\hline AG 2 & 6.87 & 24.9 & 12.50 & 166.0 & 170 & 0.00 & 0.01 & 522 & CL \\
\hline Prisons & 6.87 & 25.2 & 25.00 & 179.7 & 184 & 0.00 & 0.01 & 411 & CL \\
\hline Abetema & 7.05 & 27.7 & 260.34 & 240 & 301 & 0.00 & 0.00 & 163 & CL \\
\hline Asheresu 1 & 6.88 & 26.0 & 220.90 & 110.0 & 183 & 0.00 & 2.47 & 75 & CL \\
\hline Asheresu 2 & 6.85 & 27.4 & 170.50 & 104.7 & 180 & 0.00 & 0.23 & 71 & $\mathrm{CL}$ \\
\hline Adonteng 1 & 6.57 & 27.7 & 100.00 & 51.8 & 26 & 0.00 & 0.00 & 35 & CL \\
\hline Adonteng 2 & 6.54 & 27.9 & 95.00 & 40.5 & 44 & 0.00 & 0.00 & 28 & CL \\
\hline Dago 1 & 7.26 & 28.0 & 150.50 & 137.2 & 240 & 0.00 & 0.00 & 93 & CL \\
\hline Dago 2 & 7.28 & 27.4 & 140.90 & 132.9 & 256 & 0.00 & 0.00 & 90 & CL \\
\hline Afutu & 7.18 & 27.8 & 83.00 & 87.7 & 140 & 0.00 & 0.00 & 60 & CL \\
\hline Yaw Nyarko & 6.82 & 27.7 & 75.0 & 125.3 & 172 & 0.00 & 0.00 & 86 & CL \\
\hline Jamaica 3 & 6.41 & 27.9 & 35.00 & 53.3 & 44 & 0.00 & 0.00 & 36 & CL \\
\hline Jamaica 4 & 6.38 & 27.9 & 50.00 & 53.4 & 44 & 0.00 & 0.00 & 37 & CL \\
\hline Asuafum 3 & 6.87 & 27.7 & 140.90 & 122.5 & 132 & 0.00 & 0.00 & 36 & CL \\
\hline Asuafum 4 & 6.38 & 27.9 & 50.00 & 47.3 & 40 & 0.00 & 0.00 & 32 & CL \\
\hline
\end{tabular}


Table 2: Chemical water quality parameters

\begin{tabular}{|c|c|c|c|c|c|c|}
\hline Town/source & $\begin{array}{l}\mathrm{Ca}^{2+} \\
\mathrm{mg} / \mathrm{L}\end{array}$ & $\begin{array}{l}\mathrm{Mg}^{2+} \\
\mathrm{mg} / \mathrm{L}\end{array}$ & $\begin{array}{l}\mathrm{Cl}^{-} \\
\mathrm{mg} / \mathrm{L}\end{array}$ & $\begin{array}{l}\mathrm{NO}_{3}^{-} \\
\mathrm{mg} / \mathrm{L}\end{array}$ & $\begin{array}{l}\mathrm{PO}_{4}{ }^{2-} \\
\mathrm{mg} / \mathrm{L}\end{array}$ & $\begin{array}{l}\mathrm{SO}_{4}{ }^{2-} \\
\mathrm{mg} / \mathrm{L}\end{array}$ \\
\hline Domeabra & 79 & 47 & 39.00 & 0.43 & 1.0 & 48.90 \\
\hline Jamaica 1 & 22 & 15 & 74.45 & 0.39 & 1.7 & 35.35 \\
\hline Jamaica 2 & 24 & 20 & 67.5 & 0.24 & 1.0 & 38.63 \\
\hline Asuafum 1 & 47 & 47 & 85.08 & 0.26 & 2.0 & 87.12 \\
\hline Asuafum 2 & 19 & 30 & 67.34 & 0.20 & 2.6 & 90.34 \\
\hline PWTC & 35 & 40 & 46.08 & 0.15 & 1.7 & 69.49 \\
\hline Sectech 1 & 27 & 8 & 92.17 & 0.21 & 1.7 & 38.94 \\
\hline Sectech 2 & 15 & 12 & 56.72 & 0.41 & 2.6 & 40.49 \\
\hline Sectech 3 & 18 & 16 & 35.45 & 0.31 & 3.6 & 52.58 \\
\hline Obodan 1 & 22 & 15 & 53.18 & 0.09 & 1.0 & 60.39 \\
\hline Obodan 2 & 30 & 22 & 88.63 & 0.09 & 5.3 & 62.71 \\
\hline Pokrom1 & 108 & 79 & 102.85 & 0.19 & 0.5 & 100.18 \\
\hline Pokrom 2 & 109 & 73 & 116.98 & 0.92 & 4.2 & 105.01 \\
\hline Fotobi 1 & 76 & 79 & 113.44 & 0.24 & 2.0 & 112.37 \\
\hline Fotobi 2 & 78 & 50 & 120.52 & 0.19 & 3.6 & 110.81 \\
\hline $\mathrm{KD}$ & 21 & 18 & 31.91 & 0.11 & 1.0 & 45.63 \\
\hline AG 1 & 75 & 65 & 63.81 & 0.43 & 2.0 & 122.49 \\
\hline AG 2 & 91 & 40 & 131.17 & 0.55 & 1.0 & 117.00 \\
\hline Prisons & 96 & 55 & 131.16 & 0.25 & 2.0 & 134.43 \\
\hline Abetema & 96 & 124 & 63.81 & 0.43 & 3.6 & 193.88 \\
\hline Asheresu 1 & 105 & 47 & 71.90 & 1.00 & 4.8 & 177.13 \\
\hline Asheresu 2 & 105 & 46 & 120.53 & 0.78 & 3.6 & 163.49 \\
\hline Adonteng 1 & 11 & 9 & 53.17 & 0.23 & 5.8 & 47.37 \\
\hline Adonteng 2 & 24 & 22 & 67.36 & 0.20 & 5.8 & 52.58 \\
\hline Dago 1 & 113 & 80 & 74.45 & 0.71 & 1.7 & 200.48 \\
\hline Dago 2 & 119 & 83 & 38.99 & 0.43 & 3.6 & 197.83 \\
\hline Afutu & 87 & 32 & 60.27 & 0.73 & 2.0 & 103.7 \\
\hline Yaw Nyarko & 19 & 58 & 109.89 & 0.33 & 3.6 & 128.82 \\
\hline Jamaica 3 & 70 & 40 & 49.63 & 0.21 & 2.6 & 40.01 \\
\hline Jamaica 4 & 16 & 17 & 21.27 & 0.52 & 3.2 & 39.37 \\
\hline Asuafum 3 & 70 & 38 & 102.81 & 0.14 & 3.6 & 92.27 \\
\hline Asuafum 4 & 22 & 21 & 77.99 & 0.15 & 2.0 & 90.16 \\
\hline
\end{tabular}

AG = Aburi Girls' Sec. Sch.; T.H. = Total Hardness; PWTC = Presbyterian Women Training College; $\mathrm{CL}=$ Colourless; Alk = Alkalinity. Numbers on communities indicate the number of boreholes present. 
94 Apau et al.

Table 3: Permissible levels of some water quality parameters compared with experimental results

\begin{tabular}{llcl}
\hline Parameter & Average Value & Standard Deviation & WHO/EPA Guidelines \\
\hline $\mathrm{pH}$ & 7.01 & 0.21 & $6.5-8.5$ \\
Turbidity & $0.00 \mathrm{NTU}$ & - & $5.0 \mathrm{NTU}$ \\
$\mathrm{TDS}$ & $85.19 \mathrm{mg} / \mathrm{L}$ & 53.85 & $1000 \mathrm{mg} / \mathrm{L}$ \\
Conductivity & $82.15 \mu \mathrm{S} / \mathrm{cm}$ & 43.10 & $250 \mu \mathrm{S} / \mathrm{cm}$ \\
Alkalinity & $51.16 \mathrm{mg} / \mathrm{L}$ & 62.09 & $10-180 \mathrm{mg} / \mathrm{L}$ \\
Total Hardness & $95.46 \mathrm{mg} / \mathrm{L}$ & 59.01 & $500 \mathrm{mg} / \mathrm{L}$ \\
Ca Hardness & $57.695 \mathrm{mg} / \mathrm{L}$ & 36.76 & $\mathrm{NRV}$ \\
Mg Hardness & $42.125 \mathrm{mg} / \mathrm{L}$ & 26.89 & $\mathrm{NRV}$ \\
Chloride ion & $75.922 \mathrm{mg} / \mathrm{L}$ & 30.28 & $250 \mathrm{mg} / \mathrm{L}$ \\
Nitrate & $0.362 \mathrm{mg} / \mathrm{L}$ & 0.24 & $5 \mathrm{mg} / \mathrm{L}$ \\
Phosphate & $2.700 \mathrm{mg} / \mathrm{L}$ & 1.423 & $\mathrm{NRV}$ \\
Sulphate & $93.75 \mathrm{mg} / \mathrm{L}$ & 49.98 & $250 \mathrm{mg} / \mathrm{L}$ \\
Temperature & $26.21^{\circ} \mathrm{C}$ & 1.57 & $26.2-30.6^{\circ} \mathrm{C}$ \\
Salinity & $0.804 \mathrm{PSU}$ & 4.01 & $\mathrm{NRV}$ \\
\hline
\end{tabular}

NRV $=$ No Recommended Value

The mean $\mathrm{pH}$ value of the water samples was $6.79 \pm 0.21$. The $\mathrm{pH}$ values ranged between 6.38 to 7.28 with Jamaica 4 and Asuafum 4 had the least value. However, Dago community had the highest $\mathrm{pH}$ value. The results indicate that the water resource available to the inhabitants of the area was slightly acidic. The WHO (2011) recommended range of $\mathrm{pH}$ suitable for domestic purposes is $6.5-8.5$. This range indicates that all the water sources (Table 1) within the district meet the standard guidelines of WHO and is therefore good for consumption except for Jamaica 4 and Asuafum 4, which had a value of 6.38 , making the water resources in that community slightly more acidic than expected. According to Fatoki et al., (2002), the $\mathrm{pH}$ of a water body is very important in that it may affect the solubility and toxicity of metals in the aquatic system. Colour and turbidity are closely related and these parameters usually have a direct correlation. The experimental results in this work did not differ in any way from this assertion. All the water samples were found to be colourless. It was therefore not surprising that turbidity of the sample in the study area gave a value of $0.00 \mathrm{NTU}$ for all the samples which is below the limit of 5NTU, i.e. the standard value of turbidity of potable water set by WHO.

Pure water would theoretically have specific conductivity of zero $\mu \mathrm{S} / \mathrm{cm}$ at $25^{\circ} \mathrm{C}$. Distilled water has a specific conductivity of $1.0 \mu \mathrm{S} / \mathrm{cm}$. However, the WHO guideline value for the specific conductivity of water is $250 \mu \mathrm{S} / \mathrm{cm}$. The average specific conductivity of the samples is $82.15 \pm 43.10 \mu \mathrm{S} / \mathrm{cm}$. This value indicates that the water sample contain some amount of dissolved substances that are useful for human health. The specific conductivity 
value ranges from 29.70 to $240 \mu \mathrm{S} / \mathrm{cm}$ with $\mathrm{KD}$ and Abetema communities having the lowest and highest values respectively.

Temperature readings ranged from 24.0 to $28.0^{\circ} \mathrm{C}$ with $\mathrm{AG}$ and Pokrom as well as Dago communities having the least and highest values respectively. The mean temperature reading was found to be $26.21 \pm 1.57^{\circ} \mathrm{C}$. The WHO guideline value for the temperature of water used for domestic purposes is from 26.2 $30.6^{\circ} \mathrm{C}$. This result shows that most of the water samples from the communities fall within the certified value except for Domeabra, Jamaica 1, Jamiaca 2, Asuafum 1, Asuafum 2, PWTC, Sectech 1, Obodan 1, Fotobi 1, AG 1, AG 2 , Prisons and Asheresu 1. The temperature controls the rate of metabolic and reproductive activities.

The WHO acceptable limit of TDS for potable water is $1000 \mathrm{mg} / \mathrm{L}$. The TDS of the water samples range from $13 \mathrm{mg} / \mathrm{L}$ to $526 \mathrm{mg} / \mathrm{L}$, with $\mathrm{Sec}-$ tech and Aburi Girls having the lowest and the highest values respectively. The mean of the TDS is $85.19 \pm 53.85$. However, TDS values recorded fall below the WHO recommended limits of $1000 \mathrm{mg} / \mathrm{L}$.

Water with high salinity is toxic to both plants and animals and possess salinity hazard. This condition increases the concentrations of salt in the soil. The salinity of the water samples range from 0.00 to 2.47PSU. All the communities were found to have water which is not saline with the exception of water from Asheresu1, Asheresu 2 and Sectech 2 with values of 0.23 , 2.47 and 0.23 respectively.

The Public Health Service Standards recommend a maximum of $500 \mathrm{mg} / \mathrm{L}$ of hardness in drinking water. There is no maximum limit set by the WHO guideline. The total hardness values of the sample ranged from a minimum of 25 to a maximum of $301 \mathrm{mg} / \mathrm{L}$ with Sectech 2 and Abetema having respectively the lowest and the highest values. The mean total hardness was found to be $95.46 \pm 59.01 \mathrm{mg} / \mathrm{L}$ which falls below the accepted guideline limit of $500 \mathrm{mg} / \mathrm{L}$. Total hardness consists of hardness due to $\mathrm{Ca}^{2+}$ and $\mathrm{Mg}^{2+}$ as well as some other cations. $\mathrm{Ca}^{2+}$ hardness ranges from a minimum of 15 to a maximum of $119 \mathrm{mg} / \mathrm{L}$ with an average value of $57.695 \pm 36.7 \mathrm{mg} / \mathrm{L}$ and hardness due to $\mathrm{Mg}^{2+}$ ranges from 8 to $124 \mathrm{mg} / \mathrm{L}$ with mean value of $42.135 \pm 26.8 \mathrm{mg} / \mathrm{L}$. Calcium hardness is at all times greater than hardness due to magnesium as observed from the individual average value with the exception of some few cases such as Abetema. There is no guideline limit for calcium and magnesium hardness. Magnesium concentrations of less than $50 \mathrm{mg} / \mathrm{L}$ are desirable in potable water, although many public water supplies exceed this amount.

The alkalinity values for the samples ranged from 10 to $260.34 \mathrm{mg} / \mathrm{L}$ with Jamaica1 and Abetema having the lowest and highest values respectively. The average alkalinity value was found to be $51.16 \pm 37.51 \mathrm{mg} / \mathrm{L}$. Alkalinity is a measure of its capacity to neutralize acids and is primarily due to the presence of the salts of weak acids especially the carbonate and bicarbonates (Pant, 2010).

The WHO guideline limit for chloride ions in drinking water is $250 \mathrm{mg} / \mathrm{L}$. The highest level of residual chlorine allowed in drinking water is $4 \mathrm{mg} / \mathrm{L}$. Samples from Jamaica 4 had the least chloride ion concentration of $21.27 \mathrm{mg} / \mathrm{L}$ and that from AG 2 had the highest concentration of $131.17 \mathrm{mg} / \mathrm{L}$, all falling within the WHO guideline. The average chloride ion concentration was found to be $66.02 \pm 30.28 \mathrm{mg} / \mathrm{L}$.

The WHO has established a recommended limit of $5 \mathrm{mg} / \mathrm{L}$ for nitrate as nitrogen $\left(\mathrm{NO}_{3}{ }^{-}-\mathrm{N}\right)$ in drinking water. The nitrate concentration of the sample ranged from 0.11 to $1.00 \mathrm{mg} / \mathrm{L}$ with $\mathrm{KD}$ having the lowest concentration and Adonteng Senior High School having the highest concentration. The average nitrate concentration was found to be $0.665 \pm 0.24 \mathrm{mg} / \mathrm{L}$. Nitrate is broken down in the human intestine into nitrite. Nitrite reacts with haemoglobin in human blood to produce methemoglobin, which limits the 


\section{Apau et al.}

ability of red blood cells to carry oxygen. This accounts for the gasping behavior often observed in fish with brown blood disease, even when oxygen levels are relatively high (Laninga and Writer, 1998).

The phosphate concentration ranged from 0.5 to $5.8 \mathrm{mg} / \mathrm{L}$ with the Obodan and Adonteng communities having the lowest and highest values respectively. The average phosphate concentration was $2.645 \pm 1.423 \mathrm{mg} / \mathrm{L}$. There is no WHO guideline value accepted for phosphate ion concentration; however, it is estimated that the phosphate concentration should be low. This is because high phosphate concentration could cause eutrophication.

The WHO recommended limit for sulphate $\left(\mathrm{SO}_{4}{ }^{2-}\right)$ is $250 \mathrm{mg} / \mathrm{L}$ for drinking water. The sulphate concentration of the samples ranged from 35.35 to $200.48 \mathrm{mg} / \mathrm{L}$ with Jamaica and Dago communities having the lowest and highest values respectively. The average sulphate concentration was $93.75 \pm 49.98 \mathrm{mg} / \mathrm{L}$. This result shows that the $\mathrm{SO}_{4}{ }^{2-}$ of the water samples fall within the WHO guideline limit. The high sulphate levels in water from Dago means that the water moves through soil and rock formations that contain sulphate minerals, some of which dissolves into the groundwater. The water from Dago can be treated by the process of reverse osmosis which removes most of the sulphate.

This can be accomplished by forcing the water through a cellophane-like plastic sheet known as a semipermeable membrane.

\section{CONCLUSION}

Physico-chemical characteristics of selected priority parameters of boreholes from the communities in Aburi and its surroundings during dry seasons were determined in this study.

The slight acidic nature of borehole water from most of the communities may be due to geology, environmental factors and activities. Deleterious levels of almost all the physico- chemical parameters were observed not to exist or of very little significance. Moreover, a few of the samples such as those collected from Asuafum 4 recorded low $\mathrm{pH}$ (6.38) and in some isolated cases, other parameters of the samples recorded values outside the WHO guidelines. However, most of the borehole water from the communities in Aburi and its surroundings can be said to be of acceptable quality for household utilization using the parameters studied. Therefore the water within the study area is potable.

\section{REFERENCES}

Adeyeye, E. I. and Abulude F. O. (2004). Analytical assessments of some surface and ground water resources in Ile-Ife, Nigeria. Journal of Chemical Society Nigeria, 29: 98103.

APHA (1998). Standard methods for the examination of water and wastewater. $18^{\text {th }}$ ed. American Public Health Association, Washington, DC.

Asaolu, S. S. (2002). Determination of some heavy metals is Orechromis nicoticus, Clarias gariepinus and Synontis spp from the coastal water of Ondo State, Nigeria. Pak. Journal of Scientific and Industrial Research, 45: 17-19.

Dechesne, M., Barrand, S. and Bardin, J. P. (2004). Indicators for hydraulic pollution retention assessment of stormwater infiltration basins. Journal of Environmental Management, 71(4): 371-380.

Fatoki, O. S., Lujiza, N. and Ogunfowokan, A. O. (2002). Trace metal pollution in the Umtata River. Journal of Water South Africa, 28 (2): 183-190.

Jeong, C. H. (2001). Effect of land use and urbanization on hydrochemistry and contamination of groundwater from Taejon area, Korea. Journal of Hydrology, 253(1): 194-210. 
Physico-chemical water quality parameters ... 97

Laninga, T. and Writer, J. (1997). Boulder Creek Watershed Education Teacher's Resource Guide. Produced by the city of Boulder Water Quality and Environmental Services, Mississippi State University. Information Sheet 1390.

Ludwig, D., Hilborn, R. and Walters, C. (1993). Uncertainty, resource exploitation and conservation: lessons from history. Science, 260(2): 17.

Pant, B. R. (2010). Ground Water Quality in the Kathmandu Valley of Nepal. Environmental Monitoring Assessment, 178 (1-4): 477-485.

Rivett, M. O., Petts, J., Butler, B. and Martin, I.
(2002). Remediation of contaminated land and groundwater. Experience in England and Wales. Journal of Environmental Management, 65(3): 251-268.

Robertson, W. D., Cherry, J. A., and Sudicky, E. A. (1991). Groundwater contamination from two small septic systems on sand aquifers. Ground Water, 29(1): 82-92.

UNICEF/WHO. (2008). Progress on Drinking Water and Sanitation: Special Focus on Sanitation. New York and WHO, Geneva.

WHO. (2011). Guidelines for drinking water quality. $4^{\text {th }}$ ed, Geneva Switzerland, World Health Organization. 